\title{
Topical Occlusive Corticosteroid Therapy for the Treatment of Gingival Manifestation of Mucous Membrane Pemphigoid - a Case Report
}

\author{
Liliya Kavlakova ${ }^{1}$, Svitlana Bachurska ${ }^{2}$ \\ ${ }^{1}$ Department of Periodontology and Diseases of Oral Mucosa, Faculty of Dental Medicine, Medical University of Plovdiv, Plovdiv, Bulgaria \\ ${ }^{2}$ Department of Clinical Pathology, USBALO-Sofia, Bulgaria
}

Corresponding author: Liliya Kavlakova, Department of Periodontology and Diseases of Oral Mucosa, Faculty of Dental Medicine, Medical University of Plovdiv, 3 Hristo Botev Blvd., 4000 Plovdiv, Bulgaria; E-mail: kavlakovi@abv.bg; Tel.: +359 899357411

Received: 23 Feb 2020 Accepted: 12 May 2020 Published: 31 Dec 2020

Citation: Kavlakova L, Bachurska S. Topical occlusive corticosteroid therapy for the treatment of gingival manifestation of mucous membrane pemphigoid - a case report. Folia Med (Plovdiv) 2020;62(4):866-70. doi: 10.3897/folmed.62.e51339.

\begin{abstract}
Mucous membrane pemphigoid (MMP) is a chronic, autoimmune, subepithelial vesiculobullous disease that very frequently affects the mucous membranes and less often the skin. Oral cavity is the most commonly affected site and desquamative gingivitis (DG) is the most common manifestation. This is the main reason why dentists play a vital role in the diagnosis and managing the oral health of patients. Treatment is usually challenging, however, it only can achieve temporary symptomatic effect. We report a case of desquamative gingivitis, manifestation of MMP that was treated successfully with topical corticosteroid. The latter was applied by using of individual made custom trays to improve clinical efficacy.
\end{abstract}

\section{Keywords}

desquamative gingivitis, mucous membrane pemphigoid, topical occlusive therapy, topical corticosteroids

\section{INTRODUCTION}

Mucous membrane pemphigoid (MMP) is a chronic, autoimmune, subepithelial vesiculobullous disease that primarily affects the mucous membranes (oral, ocular, nasopharyngeal, oesophageal, laryngeal, genital) and occasionally the skin. ${ }^{1}$ The exact etiology of MMP is usually unknown. Known causative factors include severe mucosal inflammatory injury, drugs (clonidine, indomethacin, D-penicillamine), viruses, ultraviolet light, and genetic predisposition (HLA DQB1*301, Interleukin-4RA gene polymorphism) or possible association with other autoimmune diseases., ${ }^{2,3}$

MMP antigens are usually presented in lamina lucida of basement membrane, but lamina densa may also be the primary site of involvement in some cases. ${ }^{4}$ Six target antigens are associated with the clinical phenotype of MMP: BP180 (about 75\% of diagnosed patients), BP230 (25\%) usually with reactivity together with BP180, integrin subunits $\alpha 6 \beta 4$, laminin 5 (laminin-332, epiligrin), laminin 6 , and type VII collagen.

Autoantibodies (IgG) against basement membrane proteins, together with complement (C3) and neutrophils cause a subepithelial split and result in bulla formation. ${ }^{5}$

The oral cavity of MMP patients is the site that is most commonly affected in this condition. ${ }^{6}$ Therefore, dentists play a vital role in its early detection, adequate initial treatment and prevention of severe functional problems. ${ }^{7}$ The commonest intraoral site that becomes affected is the gin-

Copyright by authors. This is an open access article distributed under the terms of the Creative Commons Attribution License (CC-BY 4.0), 
giva which commonly presents as desquamative gingivitis (97\%). The sites that are less frequently affected in MMP patients are the palate $(21 \%)$, the buccal mucosa $(21 \%)$, lips (5\%), floor mouth (3\%) and the tongue (3\%). ${ }^{2,8}$

\section{CASE REPORT}

A 57-year-old woman was referred from her dentist to the Division of Oral Pathology in the Faculty of Dental Medicine, Medical University of Plovdiv, Bulgaria with a history of burning sensation, tenderness in the gums and inability to eat sour and spicy food. The patient has also noticed blister formation on the gums. The medical history revealed that these complaints have appeared since 6 months before the first visit. The patient didn't report any relevant family history and presence of allergies.

Intraoral examination revealed diffuse gingival inflammation with mild edema and evidence of erosion in the region of right upper lateral incisor and two intact hemorrhagic bullae in the region of lower lateral incisors. Heavy plaque accumulation was present around the teeth and gingival bleeding occurred with the slightest provocation with a periodontal probe (Fig. 1). Gentle manipulation of gingiva induced bulla formation in the marginal and papillary gingiva (positive Nikolsky sign). Upon physical examination, the patient presented a good health, with no evidence of other lesions in her

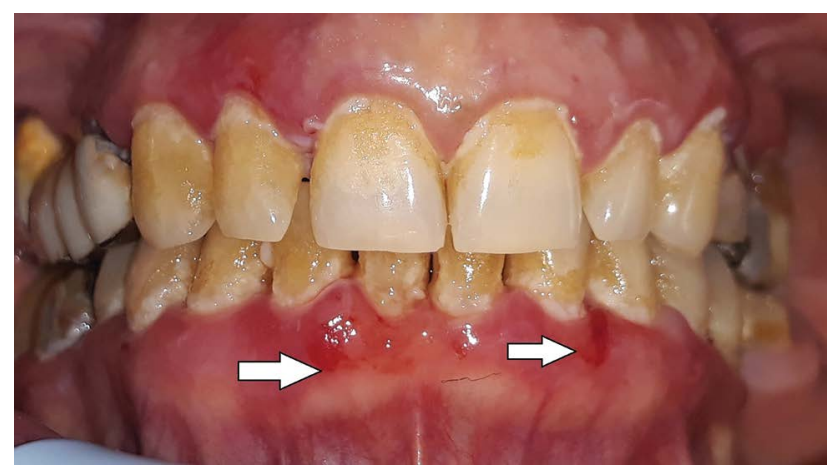

Figure 1. Initial clinical appearance - arrows show intact bullae eruption, filled with hemorrhagic fluid.

body (ocular, cutaneous or genital).

Based on the clinical findings, medical history and the positive Nikolsky's sign, a provisional diagnosis of desquamative gingivitis was made due to the vesiculobullous disorder. Differential diagnosis included mucous membrane pemphigoid, bullous pemphigoid, pemphigus vulgaris and bullous lichen planus.

\section{Clinical protocol}

An incisional biopsy material was taken from perilesional intact gingival epithelium by Er:YAG laser for histology study. The histopathologic examination showed hyper- and parakeratosis, pseudopapillomatosis and subepithelial bul- la formation (Fig. 2). A mild to moderate mixed inflammatory infiltrate was usually present in the lamina propria (predominantly lymphocytes, plasma cells and fewer eosinophils). Clinical correlation with routine histopathology confirmed the definitive diagnose of mucous membrane pemphigoid. The golden standard to diagnose MMP is di-

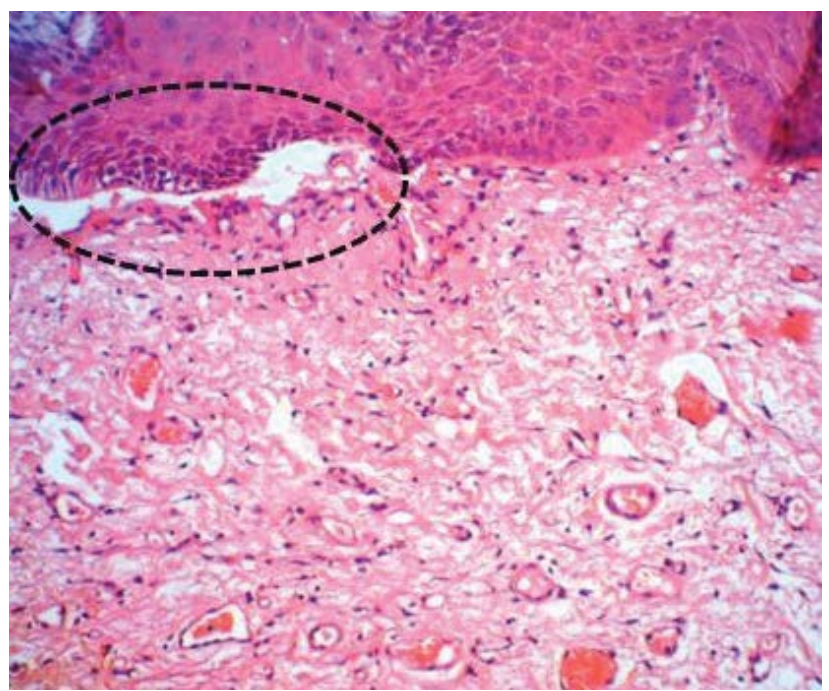

2A

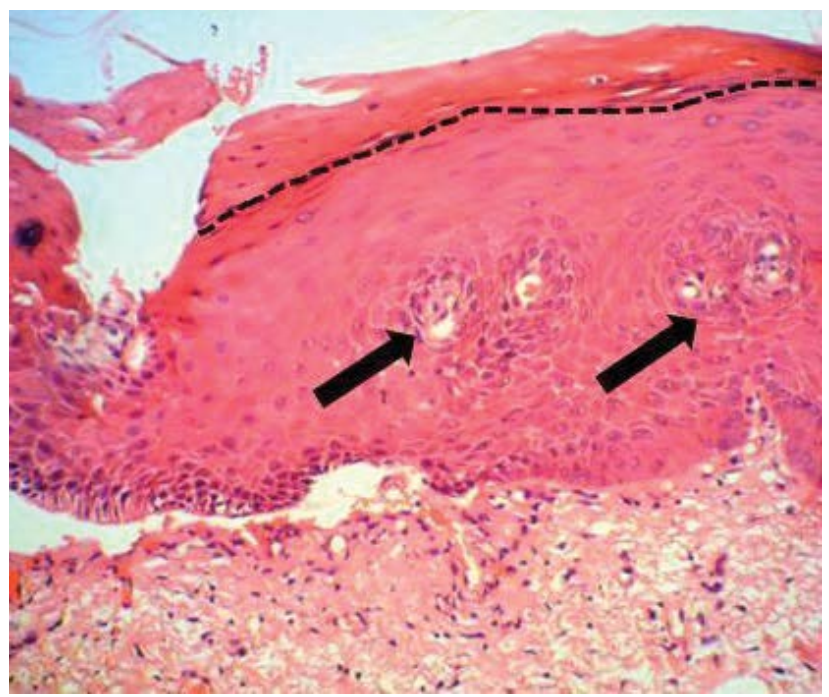

\section{B}

Figure 2. A. Black dotted line demonstrates subepithelial bulla formation; B. Black dotted line shows hyper- and parakeratosis. Arrows show pseudopapillomatosis.

rect immunofluorescence, but the patient refused to do it for financial reasons.

During the second visit, preliminary impressions were taken from the upper and lower jaws with alginate ("Hydrogum" Zhermack), for making individual custom trays similar to those described by Aufdemorte et al. ${ }^{9}$ (Fig. 3).

The splits were fabricated from silicone plates $1 \mathrm{~mm}$ thick and the edges of its reach to mucogingival junction. 


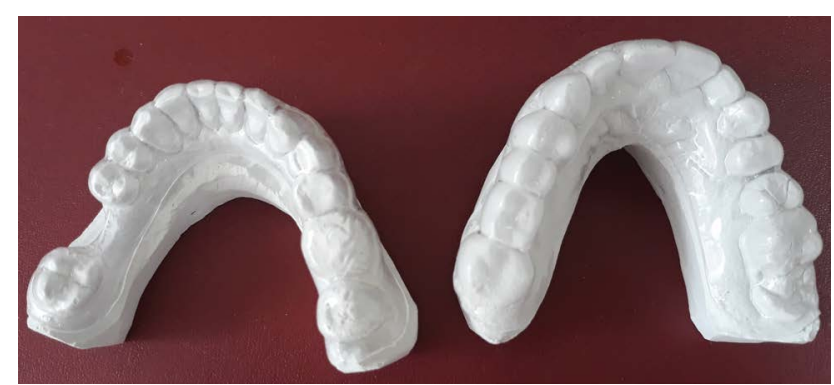

Figure 3. Study models with custom trays.

The patient was instructed to cover all internal surfaces on the split with topical corticosteroid (clobetasol propionate $0.05 \%$, dermovate cream).

The treatment took three weeks, the first two weeks the patient inserted trays twice daily, 20 minutes each time af-

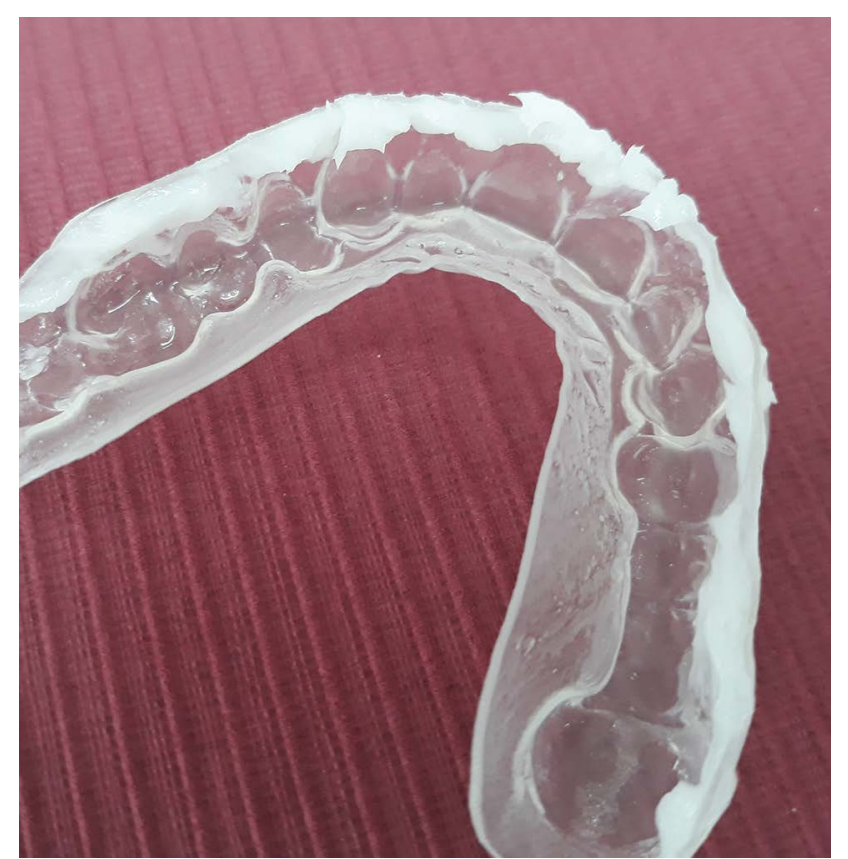

4A

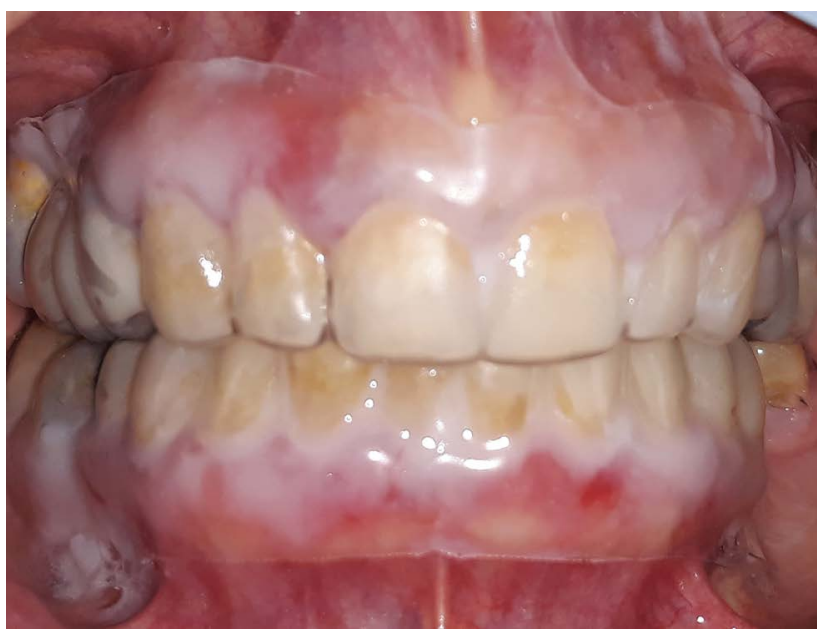

4B

Figure 4. A. Thin layer of dermovate $0.05 \%$ cream; B. Adaptation of trays in the mouth. ter oral hygiene. The topical corticosteroid was gradually tapered off over the third week - once daily (Fig. 4). The therapeutic plan of treatment was approved by the Ethics Committee of the Medical University of Plovdiv (No 4/12.12.2019). The patient was advised to expectorate excess saliva after the application and not to swallow for at least 1 hour. One of the complications of topical steroid therapy includes secondary candida infection. Therefore, concomitant antifungal prophylaxis may be necessary during the treatment (daktarin gel).

Efficacy of topical occlusive therapy was assessed by the following outcomes: primary self-reported pain the patient felt assessed by a visual analogue scale of 0 to 10 (VAS), and the clinical changes in gingiva (absence of bullae and erosions). Upon completion of therapy we found certain reduction of the VAS score: before treatment VAS score was 8 , after cessation of treatment it dropped to 2 . The lesions showed considerable improvement after administration of steroids and all areas of ulceration healed after three weeks (Fig. 5A). Proper atraumatic periodontal treatment was carried out after the acute phase of this type of gingivitis (Fig. 5B). The patient was instructed to implement optimal oral hygiene, including soft mouth rinses with diluted chlorhexidine and not to use mouth

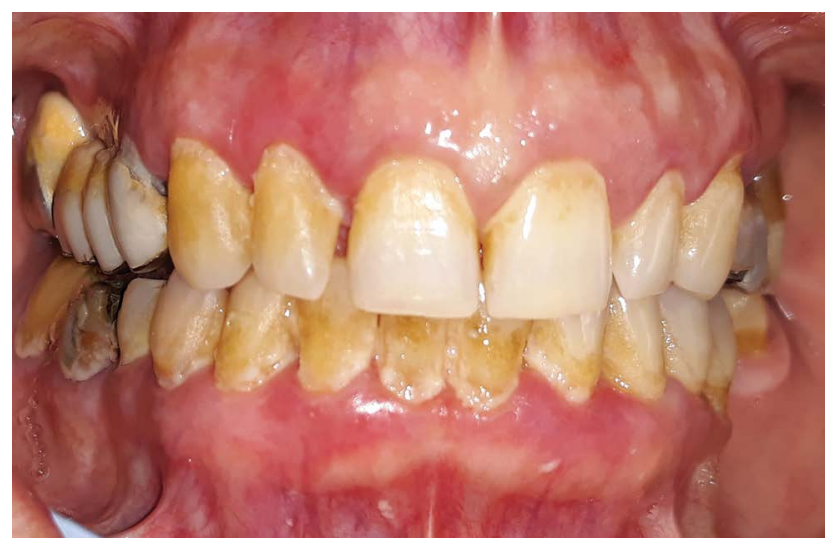

$5 A$

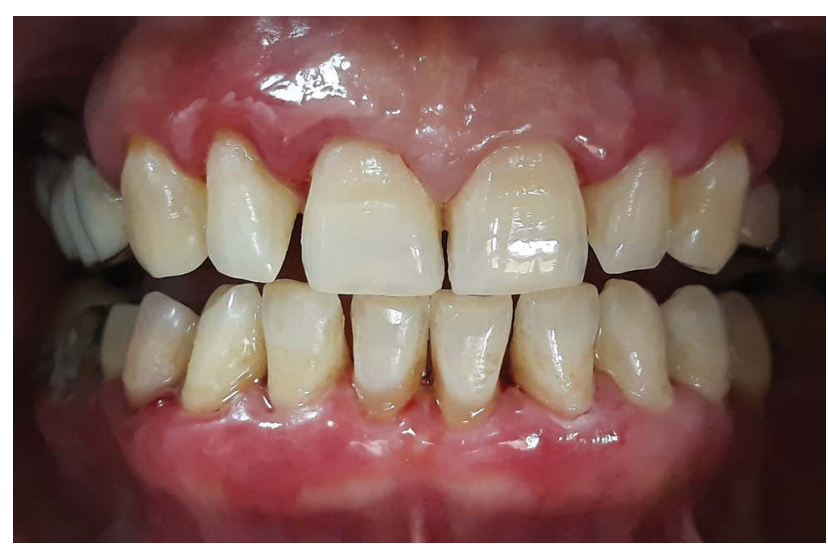

$5 B$

Figure 5. A. Clinical significant improvement after cessation of treatment; B. Clinical situation immediately after periodontal treatment. 
rinses with alcohol. A regular follow-up was done every 6 months.

\section{DISCUSSION}

The therapeutic approach in patients with oral manifestation of MMP is a major challenge in oral medicine. Several treatment modalities have been reported. However, management can achieve only temporary symptomatic effect and prolongation of the remission period. ${ }^{10}$ Treatment should be individualized for each patient depending on the disease severity, age, and general state of health. ${ }^{11,12}$

Topical corticosteroids remain the mainstay of treatment in patients with gingival manifestation of MMP. There are different methods to apply the topical corticosteroids: with gauze compresses, mouthwashes, rubbing with finger, etc. The most effective method uses custom trays or gingival veneers. ${ }^{13}$ A promising new treatment for gingival MMP is the topical use of immunomodulator tacrolimus (protopic $0.1 \%$ ), especially in patients with steroid-recalcitrant lesions. ${ }^{14}$ Recently, low-level laser therapy (LLLT) has also been used to improve the healing of tissue after local corticosteroid application. ${ }^{15}$

Patients with multiple, recalcitrant oral lesions, and involvement of other mucous membrane should be referred to their dermatologist or internist for systemic therapy. ${ }^{16,17}$

\section{CONCLUSIONS}

Dentists could be the first health professionals to recognize this multi-mucosal involvement disorder. The gingival lesions in MMP patients are usually treated by improved oral hygiene measures and topical corticosteroid therapy. The use of custom trays has been promised to improve disease control because avoids normal mouth movements that can rapidly displace the corticosteroid from its initial localization reducing the contact time between drug and lesions.

\section{REFERENCES}

1. Scully C, Lo Muzio L. Oral mucosal diseases: Mucous membrane pemphigoid. Br J Oral Maxillofac Surg 2008; 46:358-66.

2. Bagan J, Jiménez Y, Murillo J. Oral mucous membrane pemphigoid:
A clinical study of 100 low-risk cases. Oral Diseases 2018; 24:132-4.

3. Carrozzo M, Dametto E, Fasano ME, et al. Interleukin-4RA gene polymorphism is associated with oral mucous membrane pemphigoid. Oral Dis 2014; 20(3):275-80.

4. Sciubba JJ. Autoimmune aspects of pemphigus vulgaris and mucosal pemphigoid. Advances in Dental Research 1996; 10(1):52-6.

5. Shimizu H, Masunaga T, Ishiko A, et al. Autoantibodies from patients with cicatricial pemphigoid target different sites in epidermal basement membrane. The Journal of Investigative Dermatology 1995; 104(3):370-3.

6. Laskaris G, Sklavounou A, Stratigos J. Bullous pemphigoid, cicatricial pemphigoid, and pemphigus vulgaris. A comparative clinical survey of 278 cases. Oral Surg Oral Med Oral Pathol 1982; 54:656-62.

7. Arisawa E, Almeida J, Carvalho Y, et al. Clinicopathological analysis of oral mucous autoimmune disease: A 27 year study. Med Oral Patol Oral Cir Bucal 2008; 13(2):94-7.

8. Hasan S, Kapoor B, Siddiqui A, et al. Mucous membrane pemphigoid with exclusive gingival involvement: Report of a case and review of literature. J Orofac Sci 2012; 4:64-9.

9. Aufdemorte TB, De Villez RL, Parel SM. Modified topical corticosteroid therapy for the treatment of oral mucous membrane pemphigoid. Oral Surg Oral Med Oral Pathol 1985; 59:256-60.

10. Gonzalez MA, Scully C. Vesiculo-erosive oral mucosal disease management with topical corticosteroids: fundamental principles and specific agents available. J Dent Res 2005; 84(4):294-301.

11. Chan LS, Ahmed AR, Anhalt GJ, et al. The first international consensus on mucous membrane pemphigoid: definition, diagnostic criteria, pathogenic factors, medical treatment, and prognostic indicators. Arch Dermatol 2002; 138:370-9.

12. Arash A, Shirin L. The management of oral mucous membrane pemphigoid with Dapsone and topical corticosteroid. Journal of Oral Pathology and Medicine 2008; 37:341-4.

13. Gonzalez MA, Ruiz AI, Rodriguez AA, et al. Treatment of severe erosive gingival lesions by topical application of clobetasol propionate in custom trays. Oral Surg Oral Med Oral Pathol Oral Radiol Endod 2003; 95:688-92.

14. Stepkowski SM. Molecular targets for existing and novel immunosuppressive drugs. Cambridge University Press 2000; 2(4):1-23.

15. Hasan G, Basak K, Hakan B, et al. Low-level laser therapy in the treatment of mucous membrane pemphigoid: a promising procedure. $\mathrm{J}$ Periodontol 2010; 81:1226-30.

16. Neff AG, Turner M, Mutasim DF. Treatment strategies in mucous membrane pemphigoid. Ther Clin Risk Manag 2008; 4:617-26.

17. Carrozzo M, Broccoletti R, Carbone M, et al. Pemphigoid of the mucous membranes. The clinical, histopathological and immunological aspects and current therapeutic concepts. Minerva Stomatol 1996; 45:455-63. 
L. Kavlakova et al

\title{
Местная окклюзионная кортикостероидная терапия для лечения десневых проявлений пемфигоида слизистой оболочки - клинический случай
}

\author{
Лилия Кавлакова ${ }^{1}$, Свитлана Бачурска ${ }^{2}$ \\ ${ }^{1}$ Кафедра пародонтологии и заболеваний слизистой оболочки полости рта, Факультет дентальной медицинь, Медицинский университет - \\ Пловдив, Пловдив, Болгария \\ ${ }^{2}$ Отделение клинической патологии, УСБАЛО, София, Болгария
}

Адрес для корреспонденции: Лилия Кавлакова, Кафедра пародонтологии и заболеваний слизистой оболочки полости рта, Факультет дентальной медицины, Медицинский университет - Пловдив, бул. „Христо Ботев“ № 3, 4002 Пловдив, Болгария; E-mail: kavlakovi@abv.bg; Тел.: $+359899357411$

Дата получения: 23 февраля 2020 Дата приемки: 12 мая 2020 Дата публикации: 31 декабря 2020

Образец цитирования: Kavlakova L, Bachurska S. Topical occlusive corticosteroid therapy for the treatment of gingival manifestation of mucous membrane pemphigoid - a case report. Folia Med (Plovdiv) 2020;62(4):866-70. doi: 10.3897/folmed.62.e51339.

\section{Резюме}

Пемфигоид слизистых оболочек (ПСО) - хроническое аутоиммунное, субэпителиальное, везикулярно-буллезное заболевание, которое очень часто поражает слизистые оболочки, реже - кожу. Чаще всего поражается полость рта, и десквамативный гингивит (ДГ) является наиболее частым проявлением. Это основная причина, по которой стоматологи играют важную роль в диагностике и лечении полости рта пациентов. Лечение обычно сопряжено с трудностями, но может дать только временный симптоматический эффект. Мы сообщаем о случае десквамативного гингивита, проявлении ПСО, который успешно лечился местными кортикостероидами. Последние вводили с использованием индивидуальных ложек, разработанных для клинической эффективности.

\section{Ключевые слова}

десквамативный гингивит, пемфигоид слизистой оболочки, местная окклюзионная терапия, местные кортикостероиды 